\title{
Evaluation of a New Green Zirconium Nanoparticle from Lemon and Peel Extract Antioxidant and Anticancer Activity
}

\author{
Rajaa H. Salih ${ }^{1}$, Sundus Hameed Ahmed ${ }^{2}$, Rasha Sattam Hameed ${ }^{3}$, Isam Hussain T. Al-Karkhi ${ }^{4}$ \\ ${ }^{1}$ Lecturer, ${ }^{2}$ Ass. Prof., ${ }^{3}$ Ass. Lecturer, College of Science, Al-Mustansiriyah University, Baghdad, Iraq, \\ ${ }^{4}$ Ass. Prof., Former Ass. Prof., University of Baghdad
}

\begin{abstract}
Objective: This study was planned to synthesizea novel green Zirconium nanoparticles (ZrNPs), from lemon/and lemon peel with zirconium salt and test its bioactivity against free radicals, and certain cancer cell lines (MCF-7).Materials and Method: Lemon/peel extracts were prepared, mixedwith water and heated to $80^{\circ} \mathrm{C}$, and filtered. The zirconium nanoparticles were synthesized using $(\mathrm{ZrCl} 3)$ solution which was added to the filtrate (juice and peel) in 1:1 proportion, and UV-Visible was taken. Different concentrations were prepared to study their activity. DPPH assay against free radicals and cytotoxicity against MCF-7 cell line were measured. Results: UV-Visible absorbance of lemon peel/and lemon NPs was carried out and it was found that NPs gave peaks at 457 and $478 \mathrm{~nm}$, while lemon NPs gave peak at 217, and $270 \mathrm{~nm}$. antioxidant activity of all the solutions were carried out, it was found that the peel and juice nanoparticles gave the highest scavenging activity $\%$ in all concentrations at $800,600,400$, and $200 \mu \mathrm{g} / \mathrm{ml}$ which were $93,78,57$, and $20 \%$ respectively. The activity against MCF-7 cancer cell line, the highest inhibition percentage effect (95.16) showed by NPs + Peel, while the lowest effect was 18.42 .
\end{abstract}

Conclusion: Novel NPs were synthesized form $\mathrm{ZrCl} 3$ and lemon extract/and lemon peel, it was found that the last one is more active against free radical and MCF-7 cell line.

Keywords: Green zirconium NPs, lemon, peel extract, antioxidant, anticancer.

\section{Introduction}

Fruit peels were unnecessary as predictable throw away in the manufacturing of fruit juice and waste our resource and this will also cause contamination troubles ${ }^{(1)}$.

Green synthesis of metal nanoparticle is a technique to reduce the production of by products, poisonous solvents, chemical reagent, which have unhelpful and negative effect on the health of human and the environment ${ }^{(2)}$. Diverse of procedures, method, and protocols were planned to produce nano metallic

\section{Corresponding Author:}

\section{Dr. Sundus Hameed Ahmed}

Ass. Prof., College of Science, Al- Mustansiriyah University, Baghdad, Iraq, e-mail: drsundusahmed@uomustansiriyah.edu.iq, dr.alkarkhi@gmail.com particles. At present, the researchers are focusing on two major approaches that can be applied to prepare, synthesize, and produce these nanoparticles ${ }^{(3)}$.

A. The top-down by which the nanoparticles were synthesized according to its size to reduce the bulk materials using lithographic or mechanical technique such as grinding and machining ${ }^{(4)}$.

B. Bottom-up which build small materials into larger, such as synthesis of chemical compounds ${ }^{(5)}$.

Though, the major successful method and technique is the bottom-up, which allow to control the shape and the size of the nanoparticles molecule while it is grow up, this can be achieved through controlling the condition of the nanoparticles synthesis, such as temperature, pressure, $\mathrm{pH}$ of the reaction, time, concentration of the raw materials, etc. the application of the synthesized nanoparticles will be determined upon the characteristics, specification, and the composition of them ${ }^{(6)}$. The contains of lemon peel consider as a biodegradable 
materials and has a very active components that can be useful for human health such as antioxidant, vitamins (C \& D), minerals, in addition to organic compounds such as phenols, these compound make lemon peels nanoparticles promising to be used as anti bacterial, anti fungi, anti oxidant and even anti cancer. Zirconium nanoparticles that synthesized by combination of its ion with lemon peel will be more stable and can be stored for a long time compared with lemon peels and can be consider as a stable nanoparticle ${ }^{(7)}$.

Over the last few decades people use synthetic drugs for treat most diseases while the best weapon to fight illnesses is always prevention. In particular, these therapies had unselective effects towards the cells and becoming now outdated in cancer treatment due to the development of cancer prevention comes from healthy habits, many researches has focused on the antitumor activities of citrus peel compounds and nanomedicine ${ }^{(8-11)}$.

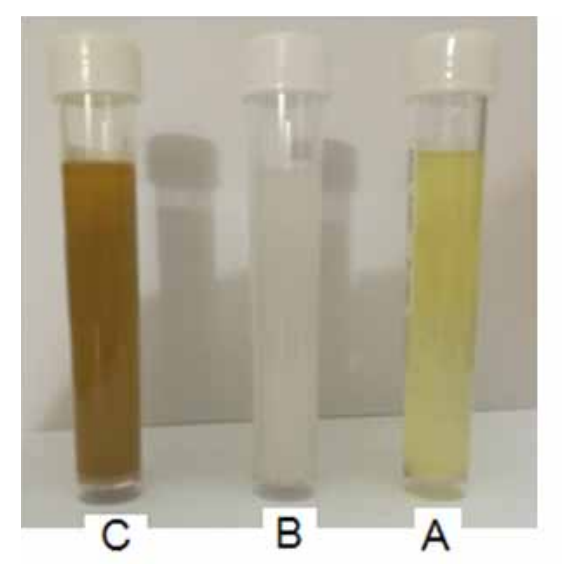

I
In this study a novel green Zirconium nanoparticles (ZrNPs) were synthesized from lemon peel with inorganic zirconium salt and test its bioactivity against free radicles, and against certain cancer cell lines (MCF-7).

\section{Materials and Method}

Preparation of juice extract powder-reducing agent: Lemon extract prepared, while the lemon peel was separated, dried, grind into powder separately. 20 $\mathrm{g}$ of grinded powder lemon peel were placed with $20 \mathrm{ml}$ of lemon juice and topped up to $1000 \mathrm{ml}$ with de-ionized water. The mixture was heated to $80^{\circ} \mathrm{C}$ in water bath, filtered, and the filtrate was stored for further use.

\section{Synthesis of Zirconium-lemon peel nanoparticles:} $0.01 \mathrm{M}$ of zirconium chloride $\left(\mathrm{ZrCl}_{3}\right)$ solution was added to the lemon juice and to the filtrate(juice and peel) in 1:1 proportion. The colored solutions and color changed as shown in figure 1 , the solution then was kept at $4{ }^{\circ} \mathrm{C}$.

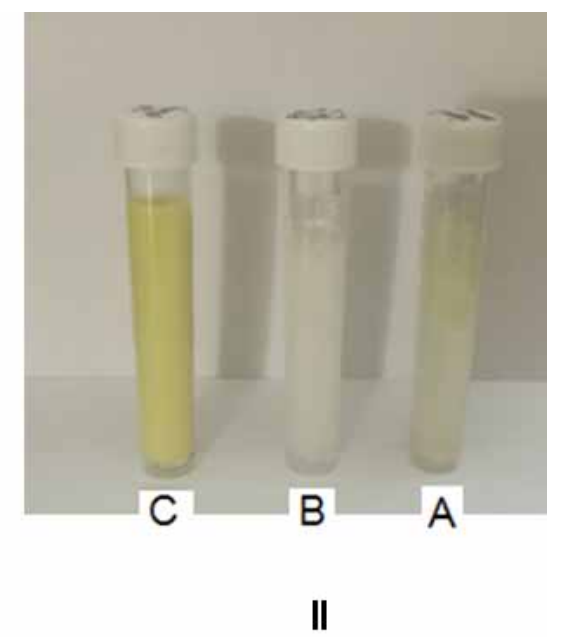

II

Figure 1: (I): A- Lemon juice extract; B-Zr Chloride solution; C- Lemon juice Zr nanoparticles. (II): A- Lemon peels extract (filtrate); B- $\mathrm{Zr}$ chloride solution; C- lemon peels nanoparticles.

\section{DPPH 2, 2-Diphenyl-1-picrylhydrazyl)/} Free Radicals (DPPH) Assay: The DPPH assay was done according to Garcia et al. 2012 method ${ }^{(8)}$, with some modifications. The colors changes were measured spectrophotometrically at $517 \mathrm{~nm}$, different concentrations (200 to $500 \mu \mathrm{g} / \mathrm{ml}$ ) of lemon extracts/ and the NPs were separately mixed with $3 \mathrm{ml}$ of $0.1 \mu \mathrm{M}$ $\mathrm{DPPH}$ and incubated in dark for $15 \mathrm{~min}$. The absorbance was measured at $517 \mathrm{~nm}$. The scavenging ability of the plant extract was calculated using this equation ${ }^{(9)}$ :
DPPHScavengingactivity $\%=\frac{(\text { Abscontrol }- \text { Abssmple })}{(\text { Abscontrol })} \times 100$

UV - Visible Spectroscopy: In order to determine the formation of iron nanoparticles in the, a spectral scanning procedure was carried out using $\mathrm{UV}-\mathrm{V}$ is spectrophotometer at the range of $300-700 \mathrm{~nm}$

Anticancer Activity: The anticancer of the synthesized nanoparticles and NPs on MCF-7(human breast cancer) cell line provided by the cell Bank Unit, 
Experimental Therapy Department, Iraqi Center for Cancer and Medical Genetic Research (ICCMGR). the cell was cultured in (RPMI)-1640 containing 10\% fetal bovine serum and $1 \%$ penicillin-streptomycin, and incubated in $\mathrm{CO}_{2}$, with humidity at $\left(37^{\circ} \mathrm{C}\right)$.

Methyl thiazolyl tetrazolium (MTT) Solution: Methyl thiazolyl tetrazolium $(0.5 \mathrm{~g})$ was dissolved in $100 \mathrm{ml}$ of phosphate buffer saline (PBS) $(5 \mathrm{mg} / \mathrm{ml}$ concentration) (Betancur-Galvis et al., 2002) ${ }^{(10)}$.

Cell culture treatment: Different concentrations of five tested compound (Nanoparticles, Lemon, NPs +Lemon, Lemon peel, NPs + Lemon peel) were prepared (300, 250, 200, 150, 100, and $50 \mu \mathrm{g} / \mathrm{ml})$ and added to the cells which seeded in 96-well transparent flat bottom plates at a density of $1 \times 10^{4}$ cells/well, There were three replicates for each tested concentration, while the last

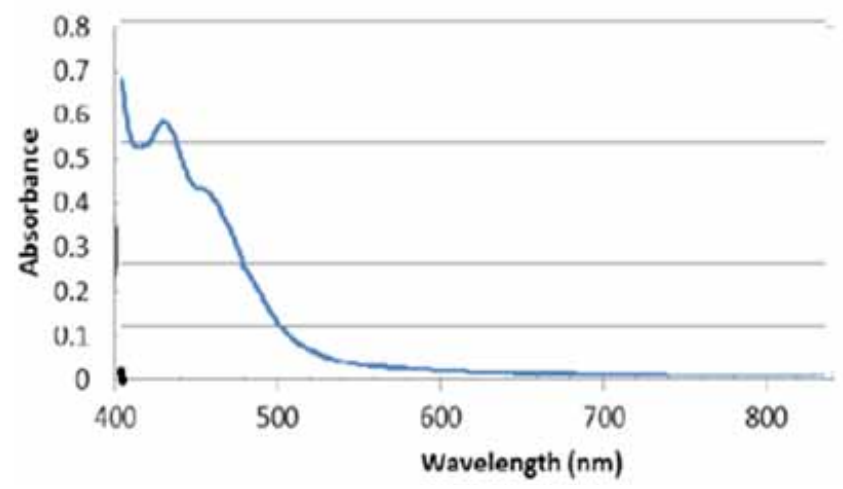

A

Figure 2: A: UV-Visible absorbance of peel NPs; B: UV-Visible absorbance of Limon juice NPs

Figure 3 illustrated antioxidant activity of nano particles of peel and juice we found that the lemon peel and juice nanoparticles gave the highest scavenging activity $\%$ in all concentrations at $800,600,400$, and column in the plate is kept as (-ve control) (cells with no treatment). The exposed transplant cells were incubated at $37^{\circ} \mathrm{C}$ and $5 \% \mathrm{CO}_{2}$, Cell viability was measured after $48 \mathrm{hr}$. of infection by removing the medium, stained the plates by MTT solution as described by ${ }^{(11)}$. The inhibiting rate of cell growth (the percentage of cytotoxicity was calculated as $(\mathrm{G} . \mathrm{I})=(\mathrm{A}-\mathrm{B}) / \mathrm{Ax} 100$, Where $\mathrm{A}$ is the mean optical density of untreated wells (control) and $\mathrm{B}$ is the optical density of treated wells (test cells) ${ }^{(8)}$.

\section{Results and Discussion}

Figure 2 showed UV-Visible absorbance of lemon peel nano particles and lemonade nano particle, it was found that peel nano particles gave peaks at 457 and $478 \mathrm{~nm}$, while lemon juice NPs gave peak at 217, and $270 \mathrm{~nm}$.

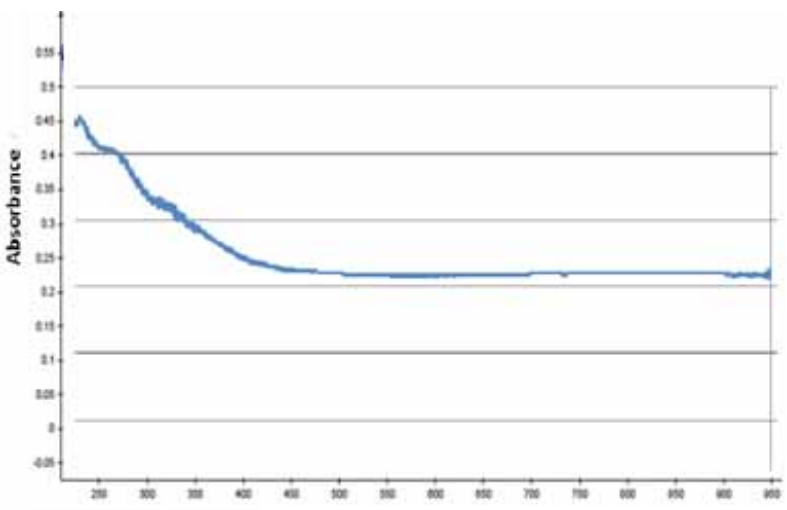

B

$200 \mu \mathrm{g} / \mathrm{ml}$ scavenging activity were $93,78,57$, and $20 \%$ for lemon peel, while for lemon juice nano particles were $64,43,38$, and $19 \%$ in compare with lemon peel extract and lemon juice extract figure 3 .

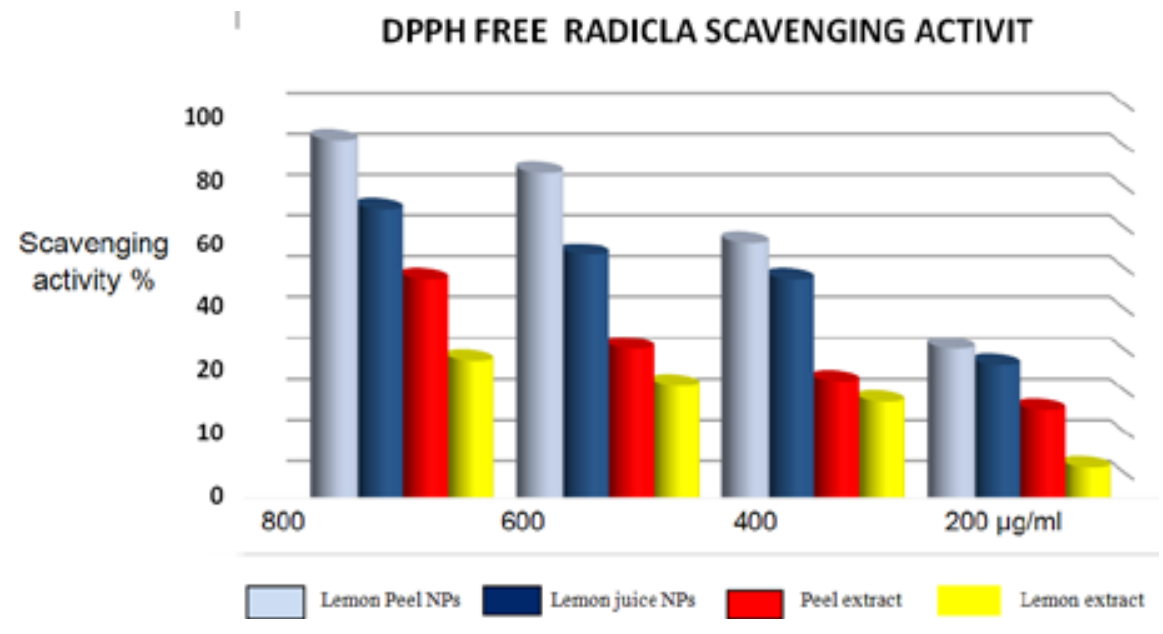

Figure 3: Antioxidant activity of nanoparticles and extracts 
MCF7 cell line were exposure the five groups of solutions were prepared with different concentration (table 1) to study their activity against MCF-7 cancer cell line, and it was found a synergism effect between the NPs and the extract while the highest inhibition percentage effect (95.16) showed by NPs + Peel at concentration of $300 \mu \mathrm{g} / \mathrm{ml}$, and the lowest effect was 18.42 showed by $25 \mu \mathrm{g} / \mathrm{ml}$ of NPs as show in table 1 .

Table 1: The growth inhibition\% of MCF-7 cell line after $48 \mathrm{hr}$. of exposure to the different combination

\begin{tabular}{|c|c|c|c|c|c|c|}
\hline \multicolumn{2}{|c|}{ Conc. $(\boldsymbol{\mu g} / \mathbf{m l})$} & \multicolumn{5}{c|}{ Inhibition\% } \\
\hline NPs & Lemon/Peel Extract & NPs & NPs+Lemon & NPs+peel & Peel Extract & Lemon Extract \\
\hline 300 & 300 & 79.15 & 92.52 & 95.16 & 64.50 & 61.91 \\
\hline 250 & 250 & 68.81 & 84.01 & 86.37 & 57.15 & 60.33 \\
\hline 200 & 200 & 63.55 & 75.42 & 79.32 & 52.59 & 49.45 \\
\hline 100 & 150 & 56.10 & 64.40 & 71.91 & 44.33 & 40.91 \\
\hline 50 & 100 & 39.49 & 56.94 & 63.15 & 36.84 & 32.33 \\
\hline 25 & 50 & 18.42 & 35.90 & 39.22 & 23.22 & 20.66 \\
\hline
\end{tabular}

NPs: Nanoparticles

Figure 4 show the comparison in cytotoxic activity toward MCF-7 cell line between control, lemon extract, and lemon peel NPs.

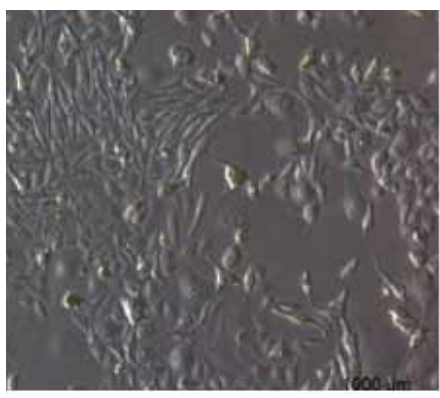

A

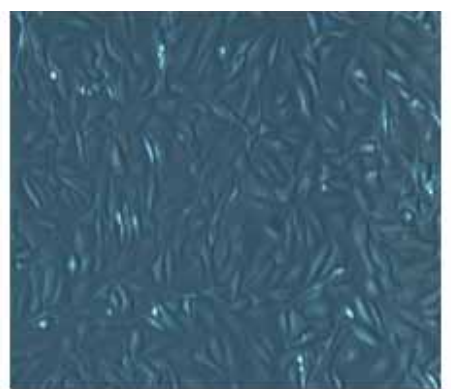

B

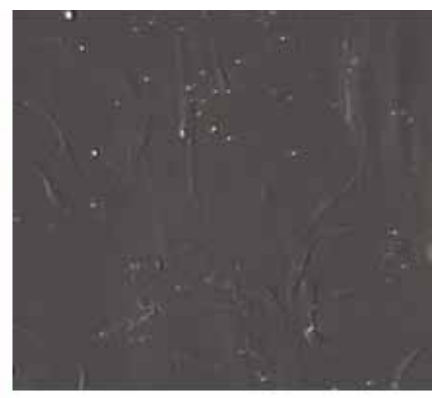

C

Figure 4: Cytotoxic activity of the compounds on MCF-7 cell lines, A: MCF7 control, B: MCF7 with lemon extract $20.66 \%$, and MCF7 NPs+ lemon peel $95 \%$

\section{Conclusions}

- Novel zirconium NPs were synthesized and characterized (lemon NPs/and lemon peel NPs).

- Free radicals (DPPH) assay was carried out successfully and it was found that lemon peel NPs shows more activity than other compounds.

- Cytotoxicity of the compounds were tested against breast cancer (MCF-7 cell line), and it was found that lemon peel NPs shows more activity than others.

Source of Funding: Self fund.

Conflict of Interest: No conflict of interest
Ethic Statement: The researchers already have ethical clearance from all required institution and laboratories.

\section{References}

1. Wei Y, Fang Z, Zheng L, Tan L, Tsang E. Green synthesis of $\mathrm{Fe}$ nanoparticles using Citrus maxima peels aqueous extracts. Materials Letters. 2016.185(15): 384-386. DOI: 10.1016/j. matlet.2016.09.029

2. Chacko S, Kannoth S. Green synthesis of iron nanoparticles from citrus lemon peel extractsfor removal of dyes congo red and brilliant green from aqueous solution. Environmental Nanotechnology, 
Monitoring \& Management. 2019; 10: 377-387. https://doi.org/10.1016/j.enmm.2018.08.003

3. Saif S, Tahir A, Chen Y. Green Synthesis of Iron Nanoparticles and Their Environmental; Applications and Implications.Nanomaterials. 2016, 6(11): 209. https://doi.org/10.3390/ nano6110209

4. Christian P, Von der FK, Baalousha M, Hofmann T. Nanoparticles: Structure, properties, preparation and behaviour in environmental media. Ecotoxicology. 2008; 17: 326-343.

5. Rotello, V.M. Nanoparticles: Building Blocks for Nanotechnology; Springer Science \& Business Media: New York, NY, USA, 2004.

6. Virkutyte J, Varma R.S. Chapter 2 Environmentally Friendly Preparation of Metal Nanoparticles. In Sustainable Preparation of Metal Nanoparticles: Method and Applications; The Royal Society of Chemistry: London, UK, 2013; pp. 7-33.

7. Murgueitio E, Cumbal L, Abril M, Izquierdo A, Debut A, Tinoco O. Green Synthesis of Iron Nanoparticles: Application on the Removal of Petroleum Oil from Contaminated Water and Soils. Journal of Nanotechnology. 2018;
2018: Article ID 4184769. 8 pages https://doi. org/10.1155/2018/4184769

8. Garcia EJ, Oldoni TLC, de Alencar SM, Reis A, Loguercio AD, Grande RHM. Antioxidant Activity by DPPH Assay of Potential Solutions to be Applied on Bleached Teeth. Brazilian Dental Journal. 2012; 23(1): 22-27.

9. Hamdia AH, Sundus HA. The Effect of Exposing the Extract of Derived Olive (Oleaeuropaea) Leaves to Microwaves in the Synthesis of Iron Oxide Nanoparticles and Inhibiting the Biological Activity of Different Types of Pathogenic Bacteria. 9th International Conference for Sustainable Agricultural Development 4-6 March 2019 Fayoum, Egypt. Journal of Agricultural Research and Development. 331(B) March, 2019.

10. Betancur-Galvis LA, Morales GE, Forero JE, Roldan J. Cytotoxic and Antiviral Activities of Colombian Medicinal Plant Extracts of the Euphorbia genus. Memorial Institution Oswaldo Cruz, Rio de Janeiro. 2002; 97(4): 541-546.

11. Mitra A, Mishra L, Shulin L.i. Technologies for deriving primary tumor cells for use in personalized cancer therapy; Trends Biotechnology. 2013; 31(6): 347-354. 